\title{
Mercy and Malice: An Inside View of the Push to Repeal and Replace Obamacare
}

\author{
Alex Garlick, The College of New Jersey
}

\section{All views and opinions expressed in this article are those of the author.}

T he early weeks of the $115^{\text {th }}$ Congress were characterized by news alerts that reverberated throughout the halls of the Capitol. Phones would buzz when the New York Times or Washington Post issued its latest report on Russia meddling in the 2016 election, President Donald Trump firing his FBI director, or a special prosecutor investigating all of the above. But one of the most consequential of these alerts had nothing to do with the dramatic Trump White House. Instead, it concerned the normally staid Congressional Budget Office's (CBO) analysis of the American Health Care Act (AHCA).

Speaker of the House Paul Ryan (R-WI) had called the AHCA an "act of mercy" to repeal the Affordable Care Act (ACA) and replace it with "patient-centered healthcare reforms" (Bryan 2017). However, on March 13, the CBO estimated 24 million Americans would lose health insurance under the bill. It was a shocking twist in the legislative saga that would define the first eight months of the Trump administration when I was working as an APSA congressional fellow on the legislative staff of Representative Joe Kennedy, III (D-MA).

This article will capture my perspective of the truths "Repeal and Replace" revealed about how the modern Congress does and does not work. The AHCA was guided through Congress by the invisible hand of party leadership at the expense of regular order. The media overlooked the mundane causes of the bill's dramatic failures to highlight intraparty squabbling. The Senate failed to live up to its self-anointed reputation as being the adults in the room. Finally, the

Alex Garlick (PhD, University of Pennsylvania), is an assistant professor of political science at The College of New Jersey. He served as a 2016-17 APSA congressional fellow in the office of Rep. Joseph P. Kennedy, III (D-MA). His research interests include lobbying, Congress and state legislatures. His website is www.alexgarlick.com and his emailis garlicka@tcnj.edu.
White House played an important role by keeping the bill from dying on multiple occasions, but this could have implications for the Republican majority.

\section{THE INVISIBLE HAND OF LEADERSHIP}

The Energy and Commerce Committee (E\&C) is the oldest standing legislative committee in the House. It was established in 1795 and has an expansive mandate. When asked about the committee's jurisdiction, former E\&C Chairman John Dingell (D-MI) would point to a photograph of planet Earth he had posted just outside the committee room to share his view of its reach (Parker 2013). This jurisdiction included health care, and since Rep. Kennedy was a member of the E\&C Subcommittee on Health, our office braced for the oncoming legislative storm.

E\&C has played an important policy making role for centuries. Regular order would dictate that a member would introduce a bill, and it would go to a subcommittee for deliberation and revisions. "Repeal and Replace" departed regular order before a bill was even released. On February 24, Politico published a draft of the bill before any Democratic members on $\mathrm{E} \& \mathrm{C}$ had the chance to review it (Demco 2017). Then the E\&C Republicans announced there would not be a subcommittee hearing, just a full-committee "markup" where committee members would ostensibly have the chance to amend the bill on March 9.

The E\&C had 31 Republicans and 24 Democrats in 2017, so Democrats had very little hope of winning any votes to amend the bill. Instead, they had a two-pronged strategy for the markup. The first was to draw attention to the backroom process, and one way to do this was to drag out the hearing. Democratic committee staff prepared over 120 amendments for the markup (E\&C Committee 2017a), the first of which changed the title of the bill to "Republican Pay More for Less Care Act” (E\&C Committee 2017b). While this was nearly a farcical suggestion, it gave each Democratic member a few minutes to discuss the amendment, which took almost three hours. The amendment was voted down on party lines. As was the next amendment, and the next. E\&C Chairman Greg Walden (R-OR), a former radio DJ, coolly and patiently dismissed each effort, so controversy would be hard to find.

The Democrats' second strategy was to highlight unpopular portions of the legislation, a "messaging" tactic that minority parties have increasingly employed (Lee 2016). For example, the Democrats proposed an amendment to ensure the bill would not reduce access to mental health services (E\&C Committee 2017c). Republicans insisted this was not a concern. But during debate, Rep. Kennedy questioned the majority staff counsel on the specifics until he admitted that the bill would do just that. The exchange led our press secretary to do a fist-pump in excitement, as he could then repackage the C-SPAN clip to share on the internet. Meanwhile, the hearing went deep into the night.

When I came to work the next morning, the hearing was in its 21st hour. I thought the hearing could go on for days. But the hopelessness of the endeavor became too obvious for the Democratic members to ignore. They conceded 27 hours in, and Chairman Walden called for the passage vote, with no substantive changes having been made to the bill. Like nearly every amendment vote, the bill passed on party lines. Speaker Ryan himself came to congratulate the Republicans on the committee. But really he was there for a victory lap of his own, as the bill was produced by his inner circle, not by a deliberative committee process.

While the vote was a lost cause, the hearing was a success in a different way. During his opening statement, Rep. Kennedy said that based on his reading of scripture, a bill that would reduce access to health care was not an "act of mercy" as Speaker Ryan had said, but rather an "act of malice." The communications team shared this video on Facebook where it quickly started to go viral. Within a few weeks, it had been viewed tens of millions of times. The American public was certainly paying attention to health care. 
THE PUBLIC, AND THE CBO, STRIKES BACK

Despite the leadership's success in pushing the bill through committee, the Republican conference was not united behind its policy substance. The day the bill was released, I was walking with Rep. Kennedy and saw Rep. Dave Brat (R-VA), a good-natured member of the conservative Freedom Caucus. Rep. Kennedy asked him what he thought of the bill and he gave a thumbs-down and said: "No way! Free market baby!"

The rest of the Freedom Caucus shared Brat's position, which put it on a collision course with the White House. One of President Trump's key campaign pledges was repealing the ACA, and his adviser Steve Bannon said: "This is not a discussion. This is not a debate. You have no choice but to vote for this bill." The Freedom Caucus did not take kindly to this, with one member saying: "The last time someone ordered me to do something, I was 18 years old. And it was my daddy. And I didn't listen to him, either" (E\&C Committee 2017c). Unsurprisingly, the infighting was front page news (Davis, Pear, and Kaplan 2017), as the media has long emphasized intraparty conflict (Groeling 2010).

Meanwhile, opposition to the bill among moderate Republicans quietly crystallized when the CBO estimated coverage losses of 24 million Americans. Polling estimated the bill to be the least popular piece of legislation in 30 years (Sides 2017), and phones across the Capitol were ringing off the hook with angry constituents. The members representing moderate districts, especially in New Jersey, New York, Pennsylvania and California were facing a difficult choice: oppose their party leadership and the White House or support a bill that their constituents hated.

The preponderance of media coverage on the Freedom Caucus did not ring true to what I was seeing in the Cannon House Office Building. The Freedom Caucus was against AHCA for ideological reasons, but the moderates were worried that if they voted for it they would be swept out of office in 2018, like many Democrats who voted for the original Affordable Care Act were in 2010 (Nyhan et al. 2012).

Whip counts published in the media (Fuller 2017) showed that Republicans did not have the votes, but they scheduled a vote for March 24 anyway. In the 24 hours before the vote was to take place, there were notable defections from the moderate camp. Rep. Rodney Frelinghuysen (R-NJ) the Chairman of the powerful House Appropriations Committee announced he was a no.

March 24 was a surreal day at the Capitol. The Republicans were scrambling; Speaker Ryan went to the White House. Just ten minutes before the vote was to take place, Trump called Washington Post reporter Robert Costa and said, "Hello Bob, so we've just pulled it" (Costa 2017) and that was it. Chairman Walden said "This bill is dead," and even Speaker Ryan admitted: "The Affordable Care Act is the law of the land" (Conway 2017).

Media coverage of the failed vote focused on the Freedom Caucus, but from where I sat, the moderates were the story. The key indicator is that the vote did not take place. The outspoken Freedom Caucus would have been happy to have their votes on the record. Meanwhile, moderates did not want to vote for the bill or oppose the White House. By taking the vote off the agenda, the Speaker was placating his moderate members.

In the media's defense, reporters can only include quotes from members who will talk to them, which creates an observation bias where the members that wanted the attention, got the attention.

\section{THEY MADE THEM VOTE FOR THAT}

After Speaker Ryan said the bill was dead, the Democrats and nearly all the Republican members were ready to move on. But the White House wanted action. At its urging, the Freedom Caucus negotiated a deal with Tom MacArthur (R-NJ), chairman of the moderate Tuesday Group. Except the deal was not much of a compromise; it made such conservative policy concessions that the Tuesday Group removed MacArthur from his role. I did not expect the compromise to move any of the conservative members.

The first week in May, our fellowship class traveled to Ottawa for an exchange program with the Canadian Parliamentary Internship Programme. Despite being in another country, a news story from back home made me spit out my Tim Horton's coffee. Rep. Fred Upton (R-MI), the former chairman of E\&C committee, went to the White House and signed off on the MacArthur deal. Upton maintained a sterling reputation and if he was lending his name to this compromise, there was something there.

Lo and behold the House passed AHCA on May 4, 2017 with a few votes to spare. This margin surprised some reporters, including Matt Fuller of the Huffington Post, who tweeted: "They made Curbelo, Issa and Amash vote for that," which could be notable in the next midterm. No Republicans were worried about 2018 on this day though, as cases of beer were wheeled into the Capitol. Trump invited the House Republicans to the White House for a boisterous celebration, although the bill had yet to be delivered to the United States Senate.

\section{"THE ADULTS IN THE ROOM"}

I was not privy to as many details on the Senate's process, but from the start it seemed messy. Before the House bill was debated in the Senate, Trump changed his tune and called it "mean" (Kenny 2017). I asked a colleague on that side of the hill about the state of play. He said: "The House assumes the Senate are the adults in the room and we'll clean it up for them."

This proved to be a difficult task. Like the House, the Senate immediately departed regular order, as Majority Leader Mitch McConnell (R-KY) organized a "working group" to draft the bill instead of the committee process. Also, the staunch opposition came from the middle, specifically Susan Collins (D-ME) and Lisa Murkowski (R-AK). The Republicans were using the budget reconciliation process, so they only needed 50 votes plus a vice presidential tiebreaker, but they could not afford to lose another vote.

With August recess looming, McConnell posed a last-ditch effort with a "Skinny Repeal" bill that ignored "replacing" the ACA. The policy specifics were almost beside the point, and the $\mathrm{CBO}$ never wavered from its estimate that millions would lose health insurance. Just before the vote on July 27, John McCain (R-AZ), Lindsey Graham (R-SC) and Ron Johnson (R-WI) held an unusual press conference where Graham called the bill "the dumbest thing in history," but they said they could back it if it would lead to a conference committee where Senate and House negotiators could craft another bill (Parmuk 2017a).

This brought the House back in the mix. That evening Speaker Ryan said: "If moving forward requires a conference committee, that is something the House is willing to do" (Parmuk 2017b). However, he notably gave no assurance that if the results of the conference did not please him that the House would not just hold a vote on "Skinny Repeal" on its own. This would have been a reckless approach to policy making, but I had begrudging respect for the Speaker's position. The Senate kicks the House around all the time, and in this case Ryan put his foot down. 
When "Skinny Repeal" came to a vote after midnight on July 28, McCain held to his word. He famously walked on the floor of the Senate and put his thumb down, joining Collins, Murkowski and every Democratic Senator to quash "Repeal and Replace."

\section{CONCLUSION}

It was a curious strategy for Congressional Republicans to pursue health care reform as their first major action of the Trump administration. While they had been eager to repeal the ACA since 2010, they never coalesced on the "replace" portion of the equation. Republicans chose to fight on an issue where Democrats held the proverbial high ground, an excellent example of Democrats having issue ownership over health care (Banda 2016).

The damage of this strategy will not be apparent until the 2018 midterm elections. Many Republicans were glad the effort appeared dead in March. But the White House continued to resurrect it, which made many Republicans in both chambers take an unpopular vote, and wasted months of legislative days.

Of course, the never-ending saga fit into the White House's communication strategy, which the New York Times Magazine called the "perpetually breaking news cycle" (Leibovich 2017). The Trump administration's constant churn of legislative activity, scandal, and the outrage it generates cancels itself out and has a way of erasing negative news, like major legislative failures.

Case in point, McCain's dramatic vote on July 28 was also my last day in DC. Later that afternoon I was waiting for my flight at Reagan National Airport next to Rep. Peter Welch (D-VT), another member of E\&C.
I wanted to ask him what he thought about McCain, but I received another news alert: Trump had fired both his Communications Director Anthony Scaramucci and Chief of Staff Reince Priebus. I forgot about health care. $\mathrm{E}$

\section{R E F E R E N C E S}

Banda, Kevin K. 2016. "Issue Ownership, Issue Positions, and Candidate Assessment. Political Communication 33 (4): 651-66.

Bryan, B. 2017. "The Obamacare Replacement Bill is an "act of mercy," and I guarantee It'll Pass the House." Business Insider, March 7. http://www. businessinsider.com/paul-ryan-obamacarereplacement-pass-act-of-mercy-2017-3

Conway, Madeline. 2017. "Ryan: "Obamacare Is The Law Of The Land" For Foreseeable Future." Politico, March 24. https://www.politico.com/ story/2017/03/obamacare-repeal-failed-paul-ryanreaction- 236478

Costa, Robert. 2017. “"Hello, Bob”: President Trump Called My Cellphone To Say That The Health-Care Bill Was Dead." Washington Post, March 24. https:// www.washingtonpost.com/powerpost/presidenttrump-called-my-cellphone-to-say-that-the-healthcare-bill-was-dead/2017/03/24/8282c3f6-10ce11e7-9bod-d27c98455440_story.html?utm_term = c704392еза75

Davis, Julie Hirschfeld, Robert Pear, and Thomas Kaplan. 2017."Trump Tells G.O.P. It's Now or Never, Demanding House Vote on Health Bill." New York Times, March 23. https://www.nytimes. com/2017/03/23/us/politics/health-republicansvote.html

Demko, P. 2017. "Exclusive: Leaked GOP Obamacare Replacement Shrinks s=Subsidies, Medicaid Expansion." Politico, February 24. https://www. politico.com/story/2017/02/house-republicansobamacare-repeal-package-235343

Energy and Commerce Committee. 2017a. Markup of Committee Print, H. Res. 154. Retrieved January 10, 2018, from https://energycommerce. house.gov/markups/markup-committee-printand-h-res-154/

Energy and Commerce Committee. 2017b. Amendment 204 to H.Res 154. Retrieved January 10, 2018, from http://docs.house.gov/meetings/IF/ IFoo/20170308/105679/BILLS-115-HR_-Poooo34Amdt-204.pdf

Energy and Commerce Commitee. 2017c. Amendment 231 to H.Res 154. Retrieved January 10, 2018, from
http://docs.house.gov/meetings/IF/IFoo/ 20170308/105679/BILLS-115-HR_-Poooo34Amdt-231.pdf

Fuller, Matt. 2017. "Republican Opposition To Health Care Bill Cracks Open Door To Negotiations." HuffPost. March 21. https://www.huffingtonpost. com/entry/republican-health-care-whip-list_us_58 d1819ae4boo705db537afa?p9jgsxkhfvjduoudi

Groeling, Tim. 2010. When Politicians Attack: Party Cohesion in the Media. New York: Cambridge University Press.

Kenny, Caroline. 2017. "Trump Confirms He Called Health Care Bill "Mean." CNNPolitics, June 26. http://www.cnn.com/2017/o6/25/politics/donaldtrump-confirms-mean-health-care/index.html

Lee, Frances. 2016. Insecure Majorities: Congress and the Perpetual Campaign. Chicago: University of Chicago Press.

Leibovich, Mark. 2017. “This Town Melts Down.” New York Times Magazine, July 11. https://www.nytimes. com/2017/07/11/magazine/washington-dc-politicstrump-this-town-melts-down.html?_r=o

Nyhan, Brendan, Eric McGhee., John Sides, Seth Masket, Steven Greene.. 2012. "One Vote Out of Step? The Effects of Salient Roll Call Votes in the 2010 Election." American Politics Research 40 (5): 844-79.

Parker, Ashley. 2013 "From 'a Child of the House' to Longest Serving Member." New York Times, June 5. http://www.nytimes.com/2013/o6/o6/us/politics/ dingell-becoming-longest-serving-congressman. html

Parmuk, Jacob. 2017a. "Health Care Vote: Four GOP Senators Threaten to Sink Skinny Obamacare Repeal." CNBC, July 27. https://www.cnbc. com/2017/07/27/mccain-graham-johnson-lay-outterms-for-supporting-obamacare-repeal.html

Pramuk, Jacob. 2017b. "Paul Ryan: House "is willing" to Work with Senate on Obamacare Repeal." CNBC, July 27. https://www.cnbc.com/2017/07/27/ paul-ryan-house-is-willing-to-work-with-senateon-obamacare-repeal.html

Shelbourne, Mallory. 2017. "Report: Bannon Told Conservatives "this is not a debate," You Have to Back Bill." The Hill. March 25. http://thehill. com/homenews/325767-report-bannon-toldconservatives-this-is-not-a-debate-you-have-tovote-for-bill

Sides, John. 2017. "Here's the Incredibly Unpopular GOP Tax Reform Plan - in One Graph." Washington Post, November 18. https://www. washingtonpost.com/news/monkey-cage/ $\mathrm{wp} / 2017 / 11 / 18 /$ heres-the-incredibly-unpopulargop-tax-reform-plan-in-one-graph/?utm term $=.264$ b223b7ao6 